\title{
DISTRIBUTION OF SULFONAMIDE COMPOUNDS BETWEEN CELLS AND SERUM OF HUMAN BLOOD
}

\author{
By MARTIN HEINEMANN 1 \\ (From the Department of Internal Medicine, Yale University School of Medicine, New Haven)
}

(Received for publication June 10, 1942)

The distribution of sulfonamide compounds between cells and serum of human blood was studied in vitro. The rate of transfer from serum to cells, and the effects of temperature and of atmosphere, were investigated. The distribution of these compounds between substrate and ultrafiltrate of serum was also observed.

\section{METHODS}

Freshly drawn blood from healthy human subjects was defibrinated by stirring with a glass rod. If hemolysis was avoided, concentrations in defibrinated and in oxalated whole blood were identical, as were concentrations in serum and in plasma. Cell concentrations were calculated from concentrations in whole blood and in plasma, and from measurements of cell volumes (1). Concentrations were expressed as mgm. per $100 \mathrm{cc}$. of water in cells and in serum, accepting, for the water of these two media, average figures (1) of 72.3 per cent and 93.5 per cent, respectively.

Since sulfonamide compounds do not dissolve rapidly, their dissolution in serum must be ascertained before the latter is added to cells. By choice of suitably low concentrations, and by incubation at $37^{\circ} \mathrm{C}$., this difficulty was overcome.

Sulfanilamide, sulfathiazole, sulfadiazene, and sulfapyridine were measured by the method of Bratton and Marshall (2), using a photoelectric colorimeter. ${ }^{2}$

Substrates and ultrafiltrates of serum were obtained according to Lavietes' method (3). It had been established previously that contact with mercury did not affect the determination of sulfonamide compounds in serum.

The effects of erythrocytes and of leukocytes (4) and of an atmosphere of nitrogen (5) upon the ratio of distribution were studied according to procedures communicated previously.

\section{EXPERIMENTAL RESULTS}

The data of Table I represent groups of similar experiments, and demonstrate the effects of time, temperature, and atmosphere upon the ratio of distribution.

1 Aided by a grant from the John and Mary R. Markle Foundation.

2 With the Evelyn colorimeter used in this laboratory, filter $\mathbf{5 4 0}$ was employed.
In similar studies, the transfer of ascorbic acid proved to be unidirectional, viz., from serum to cells only. Transfers of sulfonamide compounds, on the other hand, are freely reversible. If from whole blood containing sulfanilamide at a concentration in cells of 13.8, and in serum of $6.9 \mathrm{mgm}$. per cent, serum was removed and replaced by serum without the drug, an immediate redistribution occurred, the concentrations in cells falling to 8.3 and in serum to $3.0 \mathrm{mgm}$. per cent. No further change in concentrations was noted after shaking cells and serum at $37^{\circ} \mathrm{C}$. for 45 minutes.

Table II shows that sulfonamide compounds attain concentrations of the same magnitude in erythrocytes and in leukocytes.

The ratios of distribution of the four drugs studied are presented in Figure 1, where concentrations in cells and in serum, as stated before, are expressed as mgm. per $100 \mathrm{cc}$. of water. The

TABLE I

Effects of time, temperature, and atmosphere upon ratios of distribution

\begin{tabular}{|c|c|c|c|c|c|}
\hline \multirow{2}{*}{$\begin{array}{l}\text { Time after } \\
\text { addition }\end{array}$} & \multirow{2}{*}{ Drug } & \multirow{2}{*}{$\begin{array}{l}\text { Tem- } \\
\text { pera- } \\
\text { ture }\end{array}$} & \multirow{2}{*}{$\begin{array}{l}\text { Atmos- } \\
\text { phere }\end{array}$} & \multicolumn{2}{|c|}{$\begin{array}{c}\text { Concentration } \\
\text { in } 100 \mathrm{cc} \text {. of } \\
\text { water }\end{array}$} \\
\hline & & & & Cells & Serum \\
\hline minutes & Sulfathiazole & $\begin{array}{l}{ }^{\circ} \mathrm{C} . \\
37\end{array}$ & Air & $m g m$. & per cent \\
\hline $\begin{array}{c}\text { Immediately } \\
20 \\
40\end{array}$ & & & & $\begin{array}{l}2.9 \\
2.9 \\
2.9\end{array}$ & $\begin{array}{l}16.5 \\
16.5 \\
16.5\end{array}$ \\
\hline & Sulfanilamide & 37 & Air & & \\
\hline $\begin{array}{c}\text { Immediately } \\
20 \\
40\end{array}$ & & & & $\begin{array}{l}16.5 \\
16.5 \\
16.3\end{array}$ & $\begin{array}{l}13.5 \\
13.2 \\
13.4\end{array}$ \\
\hline 30 & Sulfanilamide & & & 14.9 & 7.0 \\
\hline 30 & Glendinan & 0 & 19ilugen & 15.0 & 7.3 \\
\hline 45 & & & $\mathrm{Air}$ & 2.8 & 9.0 \\
\hline 45 & & & & 3.0 & 9.2 \\
\hline
\end{tabular}


TABLE II

Independence of ratios of distribution from presence and absence of leukocytes

\begin{tabular}{|c|c|c|c|c|}
\hline \multirow{2}{*}{ Drug } & \multirow{2}{*}{$\begin{array}{c}\text { Erythro- } \\
\text { cytes }\end{array}$} & \multirow{2}{*}{$\begin{array}{l}\text { Leuko- } \\
\text { cytes }\end{array}$} & \multicolumn{2}{|c|}{$\begin{array}{l}\text { Concentrations in } \\
100 \mathrm{cc} \text {. of water }\end{array}$} \\
\hline & & & Cells & Serum \\
\hline Sulfanilamide & $\begin{array}{c}\text { millions } \\
4.2 \\
4.0\end{array}$ & $\begin{array}{c}\text { thousands } \\
\text { None } \\
8.4\end{array}$ & $\begin{array}{c}\mathrm{mgm} \\
15.7 \\
15.9\end{array}$ & $\begin{array}{l}\text { cent } \\
8.0 \\
8.5\end{array}$ \\
\hline Sulfathiazol & $\begin{array}{l}4.5 \\
3.8\end{array}$ & $\begin{array}{c}\text { None } \\
10.3\end{array}$ & $\begin{array}{l}4.2 \\
3.8\end{array}$ & $\begin{array}{l}12.7 \\
12.2\end{array}$ \\
\hline Sulfapyridine & $\begin{array}{l}4.5 \\
3.8\end{array}$ & $\begin{array}{l}\text { None } \\
10.3\end{array}$ & $\begin{array}{l}7.2 \\
7.1\end{array}$ & $\begin{array}{l}9.1 \\
9.4\end{array}$ \\
\hline
\end{tabular}

columns on the right hand side show the percentage of each drug ultrafiltrable from serum.

\section{DISCUSSION}

From the data presented in Table $I$, it is obvious that no gradient of transfer could be detected; analyses of samples taken immediately, and at intervals after serum containing the drug was added to cells, invariably yielded identical concentrations. The reaction associated with the transfer of sulfonamide compounds, therefore, seems to be instantaneous. This holds at $37^{\circ} \mathrm{C}$., as well as at icebox temperature. The transfer of sulfonamide compounds from serum to cells could be reversed if the concentrations in the former were reduced experimentally. The presence of oxygen was not required for this reaction, which took place in an atmosphere of nitrogen in exactly the same manner as in an atmosphere of air.

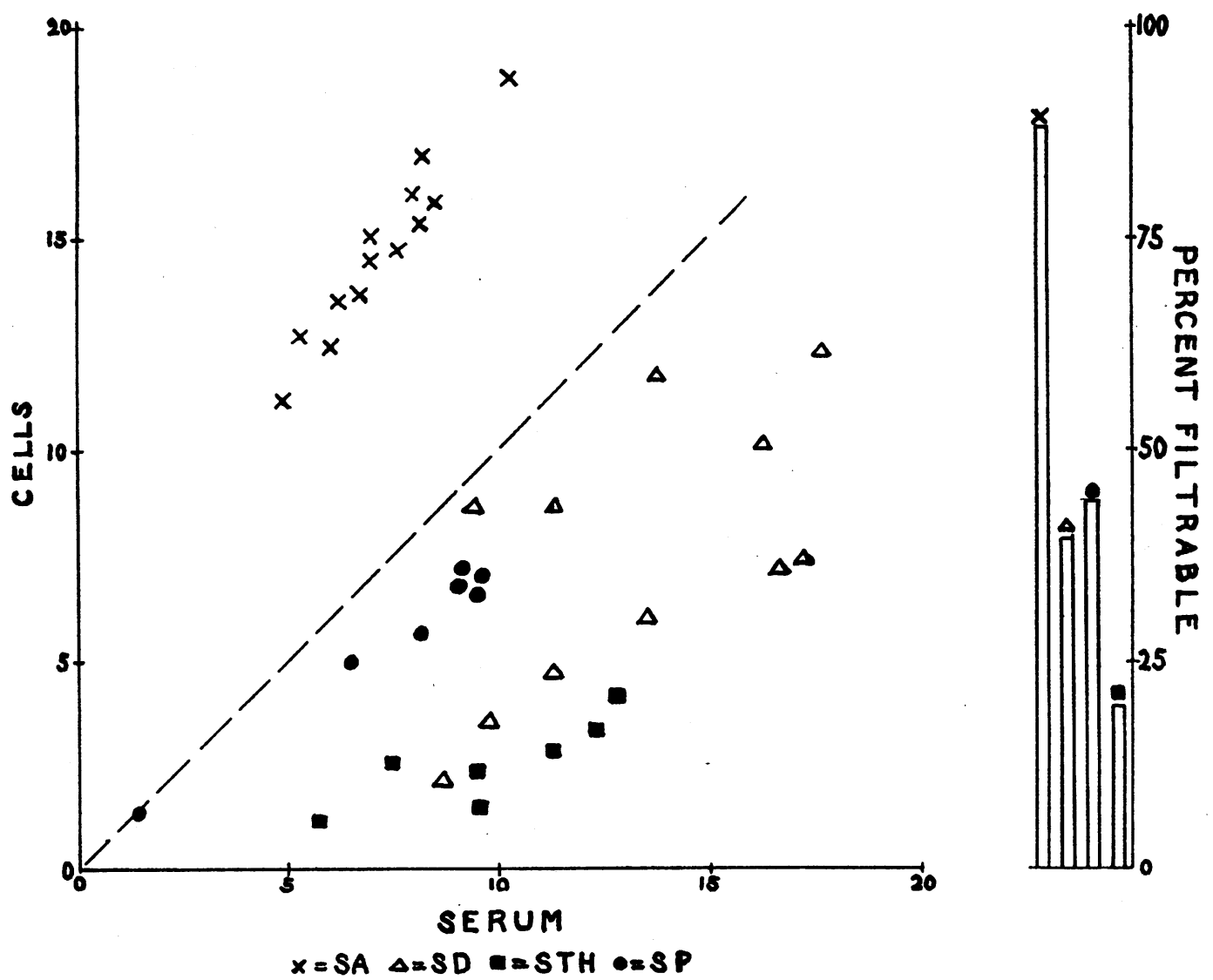

Fig. 1. Concentrations of Sulfanilamide, Sulfapyridine, Sulfadiazene, and Sulfathiazole, Expressed as mgm. in 100 cc. of Water in Cells and Serum.

On the right hand side are represented the concentrations in serum ultrafiltrates, expressed as per cent of the original serum concentrations. 
The observation that a substance like sulfanilamide passes freely in both directions (cells $\rightleftharpoons$ serum) principally excludes its use for measurements of body water. Results of experiments conducted on dogs by Elkinton and Taffel (11) have failed to corroborate a report by Painter (12) that sulfanilamide is suitable for the measurement of body fluids.

Our observations that varying percentages of the different drugs are ultrafiltrable from serum, confirm Davis' (13) report that similar proportions are diffusible when plasma is dialyzed against saline. Schoenholzer (14) and Davis (13) concluded that sulfonamides were bound to the albumin fraction of plasma protein. In this connection, it is noteworthy that the rate of diffusion of sulfonamide compounds through agar and gelatine gels was found by Hawking (15) to decrease in this order: sulfanilamide, sulfapyridine, sulfathiazole, sulfadiazene.

The free exchange of these substances between the two phases of blood, and the varying proportions of nonfiltrable drug in plasma, demonstrate the necessity of interpreting studies on clearances of these compounds with great reserve. It is obvious that such studies cannot be based on concentrations in whole blood. In in vivo experiments, such as observations on clearances, an additional fallacy may arise from difficulties which were noted while analyzing these drugs in urine. Determinations in urine to which nonacetylated drugs had been added yielded "acetylation" up to 15 per cent, which is far greater than the error of the method. Studying simultaneously original urine and urine autoclaved at $250^{\circ} \mathrm{F}$. for 30 minutes, as well as urine passed through a Seitz filter, identical proportions of acetylation were observed. Active enzymes or the presence of bacteria, therefore, can not be responsible for this change which seems to be an artefact. Urine from the same person behaved differently on different days, a change which could not be attributed to differences in $\mathrm{pH}$. It seems at present that for experimental purposes measurements of these substances in urine are not sufficiently reliable.

The amount of drug bound to plasma protein appears to be bacteriostatically ineffective. On the basis of this finding by Davis (13), and of the observation of unequal distribution, measurements of these compounds in whole blood must be considered to be less informative than measurements in serum or plasma or ultrafiltrate. With whole blood concentrations of $11 \mathrm{mgm}$. per cent for sulfathiazole and for sulfanilamide, for example, the serum concentration of the former was 16.5 , and that of the latter, $10.2 \mathrm{mgm}$. per cent. The concentration of ultrafiltrable sulfathiazole, not bound to plasma protein, would be 3.3 , and that of sulfanilamide, $8 \mathrm{mgm}$. per cent.

The ratios of distribution noted under the experimental conditions described are in agreement with observations reported by others (6 to 10).

Figure 1 demonstrates that the concentrations in cells vary with the percentage of ultrafiltrable substance in serum. The greater this percentage, the more seems available for passage into the cells. The proportion of drug bound to serum protein, therefore, appears to determine the ratio of distribution of these compounds. Such an extracellular factor appears the more likely since it could be shown that the transfers occur from serum to cells as well as from cells to serum; an intracellular reaction, like that displayed by ascorbic acid, therefore, can hardly be responsible for the concentrations of sulfonamides attained in cells.

\section{SUMMARY AND CONCLUSIONS}

Sulfanilamide, sulfathiazole, sulfapyridine, and sulfadiazene were measured colorimetrically after addition to defibrinated human blood.

The reaction associated with the distribution of these substances is instantaneous, and independent of temperature and the presence of oxygen.

Transfer of these compounds occurs, under suitable experimental conditions in both directions, from serum to cells and from cells to serum. Sulfonamide compounds attain equal concentrations in erythrocytes and in leukocytes.

The percentages of these drugs in serum ultrafiltrates vary; they correspond to the concentrations they attain in cells and seem to determine their rate of distribution in whole blood. Of the four compounds studied, only sulfanilamide was found to be more concentrated in cells than in serum; sulfathiazole, on the other hand, reached the highest relative concentration in serum.

Free passage of these compounds and varying ratios of distribution suggest that measurements 
of concentrations in plasma or in serum would be more informative than in whole blood. These observations also exclude the use of any of these substances for measurements of body fluids.

\section{BIBLIOGRAPHY}

1. Eisenman, A. J., Mackenzie, L. B., and Peters, J. P., Protein and water of serum and cells of human blood, with a note on the measurement of red blood cell volume. J. Biol. Chem., 1936, 116, 33.

2. Bratton, A. C., and Marshall, E. K., Jr., A new coupling component for sulfanilamide determination. J. Biol. Chem., 1939, 128, 537.

3. Lavietes, P. H., Anaerobic ultrafiltration. J. Biol. Chem., 1937, 120, 267.

4. Heinemann, M., Influences of erythrocytes and of leucocytes on stability and transfer of ascorbic acid in human blood. J. Clin. Invest., 1941, 20, 467.

5. Heinemann, M., and Hald, P. M., Factors that influence the passage of ascorbic acid from serum to cells in human blood. J. Clin. Invest., 1940, 19, 469.

6. Reinhold, J. G., Schwartz, L., Flippin, H. F., and Bethlahmy, S., Permeability of red blood cells to sulfathiazole. Proc. Soc. Exper. Biol. and Med., $1940,45,317$.
7. Sise, H. S., Distribution of sulfanilamide and acetylsulfanilamide between cells and extracellular fluid. Proc. Soc. Exper. Biol. and Med., 1939, 40, 451.

8. Hansen, L., Distribution of free and conjugated sulfanilamide and sulfapyridine between corpuscles and plasma in both human and rabbit blood. J. Lab. and Clin. Med., 1940, 25, 669.

9. Taylor, F. H. L., Lowell, F. C., Adams, M. A., Spring, W. C., Jr., and Finland, M., A comparative study of the blood concentrations and urinary excretion of sulfapyridine and sulfanilamide after single doses of sulfapyridine and related compounds administered by various routes. J. Clin. Invest., 1940, 19, 201.

10. Cooper, F. B., Gross, P., and Hagan, M. L., Determination and distribution of sulfathiazole in blood. Am. J. Clin. Path., 1942, 12, 149.

11. Elkinton, J. R., and Taffel, M., Prolonged water deprivation in the dog. J. Clin. Invest., 1942, 21, 787.

12. Painter, E. E., Total body water in the dog. Am. J. Physiol., 1940, 129, 744.

13. Davis, B. D., Binding of sulfonamides by plasma proteins. Science, 1942, 95, 78.

14. Schoenholzer, G., Die Bindung von Prontosil an die Bluteiweisskoerper. Klin. Wchnschr., 1940, 19, 790.

15. Hawking, F., The rate of diffusion of sulphonamide compounds. Quart. J. Pharm. and Pharmacol., 1941, 14, 226. 